\title{
Intellectual Property in the New Millennium
}

There follows the text of the inaugural lecture presented by Sir Robin Jacob on the occasion of the launch of SCRIPT.

by Sir Robin Jacob

Go back to the AHRB Centre's publication section.

"Members shall give effect to this Agreement." So begins Art. 1 of TRIPS - as the "Agreement on Trade-Related Aspects of Intellectual Property Rights" of 1994 is known.

This harmless - almost friendly - the name trips off the tongue - sounding agreement is, as a Spice Girl might say, really really important. It is an international Treaty. Its members are nations. It requires members to have a full range of intellectual property laws and that each of those laws shall have minimum standards.

For instance, by incorporation of the Berne Convention, it requires members to have copyright laws protecting "literary and artistic works" for a minimum of 50 years from the end of the author's death. Such works are defined very widely by Berne, but TRIPS goes on expressly to include computer programs too. Some might say it thus ensures the domination throughout the world of the big software companies for the foreseeable future.

For Trade Marks, any sign capable of distinguishing "shall be eligible for registration as trademarks for goods or services. And the owner shall be given the exclusive right to prevent third parties from using the identical or similar sign for the same or similar goods or services as that for which the mark is registered

For inventions, patents shall be available in all fields of technology provided they are new, involve an inventive step and are capable of industrial application. The term is to be not less than 20 years from filing. Only limited exceptions exist and only limited compulsory licensing is permitted.

TRIPS not only governs substantive law. It also contains many obligations about procedural law. "Members shall ensure that enforcement procedures are available under their law so as to permit effective action against any active infringement including expeditious remedies to prevent infringements and remedies which constitute a deterrent to further infringements". "Procedures concerning the enforcement of intellectual property rights shall be fair and equitable. They shall not be unnecessarily complicated or costly, or entail unreasonable time limits or unwarranted delays." There are requirements as to evidence, injunctions, damages, accounts of profits and availability to right holders of civil judicial procedures.

Thus TRIPS is remarkable. It requires every member state to have IP laws, and to a large extent procedures, broadly corresponding to those to be found in a fully developed western country. In some cases it may even be that western countries do not comply with its obligations. For instance, some, particularly those in poorer countries, may find it difficult to accept that the American procedure for patent infringement resolution, which on average costs about $\$ 5$ million a side, is not "unnecessarily complicated or costly".

What then of the poor countries of the world? At first sight one might simply say, "Well, TRIPS only applies to members", and why should they join this club? But they have to. TRIPS is part of a series of treaties forming the World Trade Organisation Treaties. If you want to take part in world trade you have to join that and to join that you have to join TRIPS. 
So the first question about intellectual property in the millennium is, how is TRIPS going to work out? Is it to be, as many fear, just an instrument of oppression by industrialised countries over nonindustrialised countries? Or is it to be a means of encouraging investment in such countries as some contend? I recently went to the World Intellectual Property Organisation Arab Section on TRIPS in Cairo. There was discussion about the enforcement of the copyright of computer programs. One lady from Egypt asked this question: "Our children cannot afford to pay western prices for computer programs. So if they cannot copy how can they ever learn?" Her question thoroughly deserves an answer.

Parties of judges, or about-to-be-judges, from various countries of the undeveloped or semideveloped world have been going on tours to see how western countries' judicial systems operate, with a view to implementing TRIPS in their own countries. The World Intellectual Patent Organisation and the European Patent Office (EPO) pay for them. But can one seriously envisage countries with limited scientific resources setting up anything like a Patents Court which could operate effectively? And can those countries have Patent Offices? To my mind the answer is clearly no. If TRIPS is to be implemented, some sort of way of international resolution of patent litigation would have to be devised. I think this is so anyway and it is something to which I will return. Before I do so, let me say a little more about TRIPS. Failure to implement it invites sanctions. Sanctions can be imposed pursuant to the World Trade Organisation System after hearings before an international tribunal set up by the Treaties themselves. There is the World Trade Organisation Dispute Settlement arrangement. You hear about it from time to time when there are rows between the European Union and the United States, for instance over bananas. Sooner or later there will be complaints that particular countries have failed to implement TRIPS unless politics prevents that from happening.

Whether TRIPS is really a good thing for the world is, to my mind, a wholly open question. Until now no under-developed country has become a developed country with an intellectual property right regime of the kind required by TRIPS. On the contrary, in the past under-developed countries have fashioned intellectual property rights to suit their own development. In our own country - or at least in England - patents were granted for stealing technology from other countries. The very first patent recorded is granted to a Dutchman who brought over to England the technology or an improved technology for making stained glass windows. He was given a patent provided he made the stained glass windows at Eton College and taught apprentices how to do it. He also got tax breaks. That was in about 1490. Similarly, in the United States, copyright was in effect, refused to foreigners.

Persons in the position of the defendants, that is, of agents for an American publisher, must be taken to know that Americans are in the habit of printing and exporting piratical works and they must therefore know that they import books from America at the risk of their containing what is piratical and are thus committing an unlawful act and of being liable to be sued without notice.

So says Sir George Jessel, the Master of the Rolls, in 1880. Although there were modifications, it was not really until 1957 that the Americans accorded copyright to foreigners automatically. Some of us can well remember Penguin's paperbacks with the cryptic message: "For copyright reasons this edition is not for sale in the USA or Canada" - a relic of the protectionism built into the Copyright law of the nascent US economy.

It is ironic that the now developed United States virtually imposed the terms of TRIPS on weaker countries. How it will work out, and whether the theory that TRIPS will encourage investment in such countries is true, remain to be seen.

I now turn to the question of enforcement of intellectual property rights in the new millennium. With the changes in international trade, it is increasingly apparent that the use of national courts is becoming an unsatisfactory route. I begin with the problem in Europe, focusing on patents. Under the current system each country has its own patent. A so-called European patent granted by the EPO in Münich is in law no more than a bundle of parallel national patents in the same terms. They are 
subject to the same substantive laws because each country in Europe now has the same substantive laws pursuant to the European Patent Convention. To enforce the patent, you must in theory go to each country concerned and use the courts and procedures of that country. That also was the practice until recently. As many of you will know, in recent years some continental courts have come to the idea that you can enforce patents in other countries. The Brussels Convention suggests this may be so for intellectual property rights, because it says that in any case a defendant must be sued in his home country. When you have a product subject to an intellectual property right, you can nearly always find any country you like to sue in, because you can find a defendant seller there. Having done that, then you use Article 6 of the Convention, which says you can bring in other defendants wherever they are. Thus you can choose in which country to sue in respect of the infringements right across Europe. Naturally this leads to forum shopping and to practices avoiding forum shopping.

The most recent examples of this are two cases I would like to mention. The first is Ove Arup. The plaintiff is an architect. He says that a firm of Dutch architects building Rotterdam Town Hall infringed his architectural copyright. He sues the Dutch architects and Rotterdam Town Council and the consulting engineers who necessarily will have had to use copies and the like. He sues them in respect of the Dutch copyright. The consulting engineers happen to be based in England, so he sues in England. You may ask why he does not sue in Holland, particularly as procedures there are supposed to be cheaper and quicker? The answer (almost certainly - I do not know) lies in the fact that he gets legal aid in England. Mr Justice Lloyd held that he could sue here, although his case was so thin that it should be struck out. Recently the Court of Appeal said it is not so thin and have reinstated the action. Moreover, they had gone much further than Mr Justice Lloyd in indicating the extent to which our courts can entertain infringement actions in respect of acts done in alleged infringement of foreign intellectual property rights in the countries concerned. So far as I can see, under the Court of Appeal's decision, it may be possible to sue in England in respect of an American copyright. Whether the court would have a discretion, once the defendant is properly served, to refuse jurisdiction on grounds of forum non conveniens, I do not know.

I think this is an alarming, but perhaps inevitable, development. Once one country starts using longarm jurisdiction for IP rights, then others are bound to follow - if you can't beat them, join them. There will be more and more litigation about where litigation should be. For, of course, if you know that you can be sued in country A (which you do not want), maybe the thing to do is to start proceedings for a declaration of non-infringement, or possibly revocation of rights, in country B where either you stand a better chance of winning, or at least a chance of putting off the day of judgment for so long that you can find commercial ways out of the problem.

The latest example of this has just come before Mr Justice Laddie in Sepracor v Hoechst. Hoechst made the allegedly infringing product in Germany. The parties were fighting over where they should fight. The patentee sued in England, not merely to restrain UK infringement, but infringement in a host of other countries as well. So the various associated Hoechst marketing companies in those countries were also sought to be made parties. This included the German manufacturing company. By the time of the English action, Hoechst had sued the patentee in Belgium for declarations that national designations of the patent in Belgium and Germany were not infringed, and applications were on foot to extend those proceedings to cover the French patent. Meanwhile there is an opposition running in the EPO, the effect of which, under German procedural practice, may result in a stay of any German infringement proceedings. What a shambles. This may get to the European Court of Justice, because the earlier cases referred there (Fort Dodge and Boston Scientific) have settled.

I have no doubt whatever that the current system cannot in the long term continue to exist. It is chaotic and frustrating to industry. I believe it will become more so - things have got to get worse before there will be a real effort to make them better. Some big, multi-national, companies are already thinking of "opting out" of national legal systems by agreeing to form a club whose members agree to arbitrate their IP disputes (regional or even global) in one arbitration. This shows how much 
they recognise that markets are no longer national and how, for those companies, national borders are simply irrelevant. Whether or not that idea gets off the ground I am sure we will see in the millennium the development of regional intellectual property courts.

No one should underestimate how difficult this will be. Consider the position in Europe. The European Commission came out with a Green Paper. Naively it proposed that infringement and validity be separated and that the question of validity be given to the EPO. The proposal was utterly impractical. Industry did not trust the procedures of the EPO. Moreover, nobody wanted litigation to be taking place in two courts at the same time. It is true that they do this in Germany, but many Germans think that is not a good idea. They do not do it for rational litigation reasons, but for historical and purely internal German political reasons. The Commission took that on board and have recognised that in future any European litigation system for European patents must involve the considerations of validity and infringement together.

But it has been quite unable to produce a system which industry will find acceptable. The current suggestion of a Committee of the European Parliament is, not to create a European Patent Court of First Instance, but to use specifically designated national courts. These would have imposed upon them basic procedural requirements. From these courts there would be an appeal to a common European Patent Court of Appeal, forming part of the Court of First Instance. The idea has the superficial merit that no new Treaty is required. But all this is being conducted with a degree of naiveté which is to my mind shocking. Industry is making it utterly plain that it will not trust its inventions to such a system - and why should it if it will produce much more uncertainty? Civil procedure is not a mere add-on to substantive law; it is critical. Substantive law is the bones, but procedure the flesh and blood of a living system and neither the Commission or the Parliament have really understood this.

The big differences between our systems and the continental systems lie not in the written law and not in the use of case law or not (all continental systems use case law, mostly explicitly and in some cases covertly, for instance France). The differences lie in procedure. The idea that a Greek, Italian, Finnish or British court would operate in a satisfactory manner for European industry, provided there were certain minimum requirements as to procedure, is simply nonsense. The reason that this intermediate proposal is put forward is because then it could be fitted within the existing treaties just in the same way as it has been set up, probably with fearsomely uncertain results, for the European Trade Mark. But patents are not the same as trademarks; they are technical, and the questions are much more difficult and generally more important. How you find out what the defendant is doing, or how you assess the validity of a patent, are quite different processes from those involved in trade marks. Thus the truth is, if one looks to the long term, that the setting up of a regional court for Europe is absolutely essential.

There are of course major difficulties with language. The English language is in full flood, particularly in the world of business, so business right across Europe is not that much feared by the idea of using English. Indeed, it has been French industry and Swiss industry that has been suggesting just one language. They have to write patents in English for the United States. It is the English language version which is sent to Japan for translation. So why not just use English all the time? As one Dutch Judge put it to me: "It is a pity you joined the Common Market". Somewhat alarmed, I said, "Why?" He said: "Because otherwise the original Six could all have agreed to use English."

My expectation is that within the early part of the next millennium there will indeed be a proper European Patent Court. Moreover, it will lead the way to other jurisdictions of a federal nature across Europe. Other intellectual property rights will almost certainly follow. One could even envisage such a court for more general commercial law. In other parts of the world I suspect there will also have to be developments of regional Patent Offices and regional courts. If one goes well in to the millennium, one may even find with a truly global economy, world courts. To some extent maybe 
the pre-cursors of such courts are to be found in the WTO Tribunals set up to deal with disputes between countries concerning international trade.

What is certain to my mind is that such courts will have to have a degree of specialisation. They will have to have some reasonably good understanding of intellectual property law and of the technical nature of its procedures and structures. It is almost self-evident in the case of patents. The thought that the current European Court or Court of First Instance should be dealing with technical questions of patent law makes industry quail. Indeed, the Court of Justice, now facing technical questions of trade mark law following the implementation of the Trade Mark Directive, is producing decisions calculated to create uncertainty for industry, or to produce results inconsistent with fundamental concepts of intellectual property law. I conclude by criticising two recent decisions of the Court of Justice. They show what can happen when an inexperienced court faces technical questions of IP law.

The first is the Silhouette Case. The court held that if one imports goods bearing the trade mark of an international manufacturer applied outside the European Union into Europe without that manufacturer's permission, then there is infringement of the corresponding national or European trade mark. So if you import Kodak film from France to this country there is no infringement, but if you import Kodak film from the United States to this country there is infringement. They reach this conclusion by the so called doctrine of "exhaustion". But that doctrine, whilst it makes some sort of sense in patents and copyright, is inimical to the very nature of a trade mark. "Kodak" means the goods of the Kodak company wherever the goods were made. When you import Kodak film, the name "Kodak" still tells the truth that this is Kodak's film. No rational trade mark law would allow any other result. Interestingly, within days of the Silhouette decision, British Ministers were querying it (even though the United Kingdom Government had supported the ultimate result).

The other case is more technical. The European Trade Mark Directive at many points refers to "similar goods", both when one has to obtain registration and in relation to infringement. One form of infringement is the use of the same or a similar mark for the same or similar goods. What is meant by similar goods? If you have a strong mark, Kodak is the paradigm, then if it was used for almost any goods, say socks, there is likely to be a confusion. It is a unique name. So are socks similar to film? And does the question of similarity of goods get involved with the degree of distinctiveness of the mark? I said no in a case called Treat. The Court of Justice has said yes in a case called Canon. Nowhere in the Court of Justice's reasoning is there any consideration of the fact that the distinctiveness of marks may vary with time, that by making the question of similarity of goods part of the overall question of confusion, it is introducing in to the system complex questions of fact at the registration stage and at the infringement stage, reducing cases to what might be called old fashioned passing off. I think the Court of Justice had overlooked the simple fact that the trade mark registration system is not the only system for preventing the public being deceived. Every country in Europe has a form of unfair competition; some go further than others, but they all extend to stopping deceptive conduct. There was no need for the Court of Justice to inject this massive uncertainty in to the trade mark system of Europe. If it had a better feeling for intellectual property, it would not have done so.

Thus I see for the future a need to create a system of litigation in which international courts with a good degree of knowledge of intellectual property over all its aspects are able to apply a holistic approach to the solution to the problems. Those courts will have to be good enough to serve the industries which depend more and more on IP rights.

I would like to conclude by saying how much I welcome Shepherd and Wedderburn's initiative in supporting the Centre for Research into Intellectual Property and Technology in the Edinburgh Law School. By so doing, they no only indicate their commitment to this sort of law as a law firm, but they go further. They show that they have understood the real importance of this area of law for society as a whole. I hope that the Centre will be able to devote real attention to IP procedure - the 
subject of central importance for IP as it enters the new millennium.

Thank you for inviting me to be the first President of the Centre and for inviting me to Scotland." 